BERGAMASCHI, Joice Duarte Gonçalves; AROSEMENA, Rebeca Isabel Muñoz; GOMES, Sergio Alves. A sustentabilidade como um valor. Revista Eletrônica Direito e Política, Programa de Pós-Graduação Stricto Sensu em Ciência Jurídica da UNIVALI, Itajaí, v.13, n.3, 30 quadrimestre de 2018. Disponível em: www.univali.br/direitoepolitica - ISSN 1980-7791

\title{
A SUSTENTABILIDADE COMO UM VALOR
}

\author{
SUSTAINABILITY AS A VALUE
}

Joice Duarte Gonçalves Bergamaschi ${ }^{1}$

Rebeca Isabel Muñoz Arosemena ${ }^{2}$

Sergio Alves Gomes ${ }^{3}$

SUMÁRIO: Introdução; 1 A Constituição e sua relação com os valores humanos; 1.1 A proteção dos valores humanos; 1.2 A efetividade dos valores constitucionais; 2 O ser humano e sua relação com a natureza; 3 As dimensões da sustentabilidade; 4 A sustentabilidade como um valor; Considerações finais; Referências das fontes citadas.

\section{RESUMO}

O avanço depredatório do homem sobre o meio ambiente e as consequências nocivas que isso tem causado tem levantado a discussão a respeito de quais valores devem permanecer e quais devem ser alijados. Partindo da premissa de que os indivíduos têm o seu bem-estar intimamente ligado à plena harmonia do espaço em que vivem, o estudo se utiliza do método dedutivo para enfatizar que a sustentabilidade deve ser encarada como um valor constitucional detentor de natureza multidimensional, que justifica a atuação do Poder Judiciário no amparo de interesses que sejam compatíveis com a promoção do pleno desenvolvimento da sociedade, que vai muito além do crescimento econômico expresso em valores numéricos.

Palavras-chave: valores; constituição; ações humanas; sustentabilidade.

1 Mestranda em Direito Negocial pela Universidade Estadual de Londrina - UEL/PR, com Bolsa CAPES. Pós-graduada em Direito Previdenciário pela Universidade Paranaense - UNIPAR/PR. Bacharel em Direito pela Universidade Paranaense - UNIPAR/PR. E-mail: joicedto@hotmail.com. CV: http://lattes.cnpq.br/7558439735579054.

2 Mestranda em Direito Negocial pela Universidade Estadual de Londrina - UEL/PR, com Bolsa CAPES. Graduada em Direito e Ciências Políticas pela Universidad de Panama - U.PANAMA. E-mail: munozrebeca09@gmail.com. CV: http://lattes.cnpq.br/1388307525113294.

3 Doutor em Direito pela Pontifícia Universidadade Católica de São Paulo - PUC/SP. Mestre em Direito das Relações Sociais, pela Universidade Estadual de Londrina - UEL/PR. Pós-graduado em Filosofia Política pela Universidade Estadual de Londrina - UEL/PR; Bacharel em Direito pela Pontifícia Universidade Católica do Paraná - PUC/PR. Professor associado da Universidade Estadual de Londrina - UEL/PR. Juiz de Direito aposentado. E-mail: sergiodinaura@uol.com.br. CV: http://lattes.cnpq.br/7748898800654866. 
BERGAMASCHI, Joice Duarte Gonçalves; AROSEMENA, Rebeca Isabel Muñoz; GOMES, Sergio Alves. A sustentabilidade como um valor. Revista Eletrônica Direito e Política, Programa de Pós-Graduação Stricto Sensu em Ciência Jurídica da UNIVALI, Itajaí, v.13, n.3, $3^{\circ}$ quadrimestre de 2018. Disponível em: www.univali.br/direitoepolitica - ISSN 1980-7791

\section{ABSTRACT}

The depredatory advance of man on the environment and the harmful consequences that this has caused has raised the discussion as to which values should remain and which should be suppressed. Based on the premise that individuals have their well-being intimately linked to the full harmony of the space in which they live, the study uses the deductive method to emphasize that sustainability must be considered as a constitutional value that has a multidimensional nature, which justifies the Judicial Branch acting in support of interests that are compatible with the promotion of full development of society, which goes far beyond economic growth expressed in numerical values.

Keywords: values; constitution; human actions; sustainability.

\section{INTRODUÇÃO}

A Constituição Federal de $1988^{4}$ indica dentro do preâmbulo e também no seu artigo $1^{\circ}$ os valores prioritários da República Federativa do Brasil. Assim, há tutela da liberdade, da segurança, do bem-estar, do desenvolvimento, da igualdade e da justiça, sendo que estes valores são nortes, fundação e fonte de proteção para a nação brasileira. No corpo da Constituição ainda são incluídos outros valores, focados em questões mais específicas. A promoção do meio ambiente, a seu turno, é exaltada pelo artigo 225, que concede a todos, de igual forma, o direito de viver em um ambiente sadio e ecologicamente equilibrado.

As ações humanas, individuais ou dentro de um grupo na sociedade, têm enorme potencial destrutivo sobre o meio ambiente, que não pode continuar a ser prejudicado pelo comportamento irresponsável daqueles que retiram dele o sustento para a vida. Todo comportamento humano tem impactos positivos e/ou negativos, mas a reiteração de ações desvinculadas de compromisso para com o bem-estar das gerações presentes e futuras significa que não apenas o meio ambiente sofre com as consequências diretas ou indiretas destas condutas, mas também toda a raça humana.

A proteção do meio ambiente é realizada por meio de uma das perspectivas da sustentabilidade, que mais que proteção ecológica, diz respeito à tutela dos espaços humanos que traduzam bem-estar físico e psíquico aos indivíduos, e isso,

\footnotetext{
${ }^{4}$ BRASIL. Constituição da República Federativa do Brasil. Brasília: Congresso Nacional, 1988.
} 
BERGAMASCHI, Joice Duarte Gonçalves; AROSEMENA, Rebeca Isabel Muñoz; GOMES, Sergio Alves. A sustentabilidade como um valor. Revista Eletrônica Direito e Política, Programa de Pós-Graduação Stricto Sensu em Ciência Jurídica da UNIVALI, Itajaí, v.13, n.3, 30 quadrimestre de 2018. Disponível em: www.univali.br/direitoepolitica - ISSN 1980-7791

no entendimento de Juarez Freitas ${ }^{5}$, envolve uma multiplicidade de dimensões, a saber, as dimensões ambiental, ética, social, econômica e jurídico-política. Por isso, o presente trabalho considera incentivar ações fundamentais para enfatizar, dentro da sociedade, condutas sustentáveis por meio da união entre sustentabilidade e valores humanos.

Para analisar e explicar fenômenos particulares dentro da sustentabilidade como um valor, a metodologia utilizada é de abordagem dedutiva, com atenção primordial à técnica de pesquisa bibliográfica e jurisprudencial. O objetivo é demonstrar que a sustentabilidade deve ser considerada um valor, a fim de compreender a importância de suas múltiplas dimensões para a promoção e proteção do centro do bem-estar dos indivíduos.

A pesquisa ganha importância porque a promoção da sustentabilidade não pode acontecer se não brotar como verdadeiro valor humano, que deve ser protegido e incentivado pelo poder público e por meio de ações provindas de toda a sociedade. A hipótese, então, dá ênfase à atuação do Poder Judiciário, que, por meio da equânime ponderação de interesses, permite o amparo de valores de sustentabilidade quando dá efetivo cumprimento ao documento mais representativo do Estado: a Constituição.

\section{A CONSTITUIÇÃo E SUA RELAÇÃo COM OS VALORES HUMANOS}

A vida de cada ser humano está contida em valores. Cada ação humana, individual ou em grupo (no trabalho, na igreja, em uma reunião), está direcionada a objetivos que se pretende obter. Estas condutas, por sua vez, apenas poderão realizar-se de acordo com os valores com os quais as pessoas foram educadas ou por meio do que, intimamente, consideram ser correto.

O ordenamento jurídico dos Estados expressa o conjunto dos valores mais importantes daquela sociedade e é instituído de modo a fornecer aos indivíduos o conjunto de regras de conduta que permitirão a pacífica coexistência entre eles. As pessoas, por sua vez, respeitam as regras não apenas por conta do seu caráter

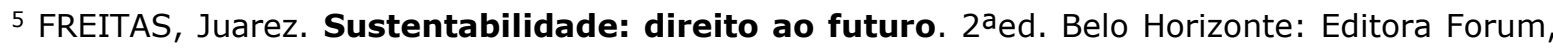
2012, p. 41. 
BERGAMASCHI, Joice Duarte Gonçalves; AROSEMENA, Rebeca Isabel Muñoz; GOMES, Sergio Alves. A sustentabilidade como um valor. Revista Eletrônica Direito e Política, Programa de Pós-Graduação Stricto Sensu em Ciência Jurídica da UNIVALI, Itajaí, v.13, n.3, 30 quadrimestre de 2018. Disponível em: www.univali.br/direitoepolitica - ISSN 1980-7791

coercitivo ou por medo de serem punidas, mas porque sabem que elas foram produzidas em seu benefício e a seu favor.

\subsection{A PROTEÇÃO DOS VALORES HUMANOS}

Para entender a construção e proteção dos valores humanos é necessário estabelecer, primeiramente, a definição geral da expressão "valor", e, posteriormente como ela atinge o Direito e a Filosofia.

A autora Milagros Otero Parga 6 explica que dar "valor" é atribuir uma importância superior a um tópico em específico de modo que daquela importância decorrem obrigações a serem incutidas a certa pessoa, individualmente, ou a determinado grupo dentro de uma sociedade. $\mathrm{E}$, de acordo com o ponto de vista, os valores podem ser definidos de diferentes maneiras. De modo geral, são considerados valores as atitudes pensadas por um indivíduo ou um grupo de indivíduos em uma coletividade, com o objetivo de realizar determinadas ações direcionadas a um resultado.

A proteção dos valores humanos fundamentais é realizada por meio do ordenamento jurídico dos países. Deste modo, o valor jurídico é uma forma ontológica de considerar a lei, é o bem legal compreendido do início até o fim. Os valores tendem a ser progressivamente convertidos em princípios e os princípios em normas, fazendo com que os valores sociais sejam a base inicial para a realização das normas ${ }^{7}$.

Os valores são, então, a base sobre a qual os princípios e as normas são especificados. Os princípios, em sentido estrito, supõem trabalhar em valores. A partir daí, Milagros Otero Parga $^{8}$ aduz que os valores hoje não são meras declarações de vontade, são critérios legais básicos e obrigatórios, com a função

6 PARGA, Milagros Otero. Valores constitucionales: introducción a la filosofia del derecho: axiología jurídica. Universidade, Servicio de Publicación e Intercambio Científico: Santiago de Compostela, 1999, p.13.

7 PARGA, Milagros Otero. Valores constitucionales: introducción a la filosofia del derecho: axiología Jurídica, p.15.

8 PARGA, Milagros Otero. Valores constitucionales: introducción a la filosofia del derecho: axiología Jurídica, p.15. 
BERGAMASCHI, Joice Duarte Gonçalves; AROSEMENA, Rebeca Isabel Muñoz; GOMES, Sergio Alves. A sustentabilidade como um valor. Revista Eletrônica Direito e Política, Programa de Pós-Graduação Stricto Sensu em Ciência Jurídica da UNIVALI, Itajaí, v.13, n.3, 30 quadrimestre de 2018. Disponível em: www.univali.br/direitoepolitica - ISSN 1980-7791

de ordenar a convivência e estabelecer os fins a serem alcançados pelos homens que vivem na sociedade.

Milagros Otero Parga ${ }^{9}$ ainda indica que os valores têm uma dimensão tripla: a primeira delas é uma função fundamental, está configurada como núcleo básico ou informante de todo o sistema jurídico político; a segunda função, de orientação, propõe metas para objetivos e fins cujo estabelecimento anterior torna ilegítima qualquer regra que persiga fins ou obstaculize a consecução dos primeiros; a terceira função é a crítica e serve como um parâmetro de avaliação de fatos e comportamentos, uma vez que todas as outras regras da ordem serão medidas de acordo com os valores previamente estabelecidos ${ }^{10}$.

Os valores constitucionais, por sua vez, estabelecem um sistema de preferências dentro da coexistência social, ao tratar opções de caráter ético, social e político. Os valores constitucionais são configurados num contexto axiológico preciso, sendo o contexto prévio da interpretação que deve fazer o ordenamento jurídico. Servem de guia para a orientação evolutiva da Constituição, bem como critério para estabelecer a legitimidade de todas as manifestações do sistema legal.

Sergio Alves Gomes ${ }^{11}$ destaca que a Constituição Federal do Brasil de 1988 traz os valores fundamentais do ordenamento jurídico brasileiro em seu Preâmbulo e no Título I (artigos $1^{\circ}$ a $4^{\circ}$, especificamente), numa dinâmica que não se afasta da perspectiva da Teoria Tridimensional do Direito de Miguel Reale ${ }^{12}$, que determina que para uma norma existir, deve haver um valor consagrado antes dela.

Assim, a fim de salvaguardar os valores supremos de uma sociedade fraterna, pelo exercício de direitos individuais e sociais, liberdade, segurança, desenvolvimento, igualdade, e justiça, a Constituição de $1988^{13}$ incita em seu preâmbulo o uso de

\footnotetext{
9 PARGA, Milagros Otero. Valores constitucionales: introducción a la filosofia del derecho: axiología Jurídica, p. 29.

10 PARGA, Milagros Otero. Valores constitucionales: introducción a la filosofia del derecho: axiología Jurídica, p. 29.

11 GOMES, Sergio Alves. Hermenêutica constitucional: um contributo à construção do estado democrático de direito. Curitiba: Juruá, 2008, p. 209.

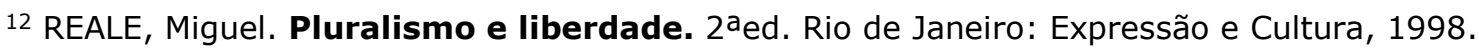

13 BRASIL. Constituição da República Federativa do Brasil.
} 
BERGAMASCHI, Joice Duarte Gonçalves; AROSEMENA, Rebeca Isabel Muñoz; GOMES, Sergio Alves. A sustentabilidade como um valor. Revista Eletrônica Direito e Política, Programa de Pós-Graduação Stricto Sensu em Ciência Jurídica da UNIVALI, Itajaí, v.13, n.3, $3^{\circ}$ quadrimestre de 2018. Disponível em: www.univali.br/direitoepolitica - ISSN 1980-7791

meios pacíficos de resolução de conflitos, que resguardem a harmonia social e a ordem interna e internacional como diretrizes do sistema brasileiro.

Ainda no cunho axiológico, a Constituição Federal de $1988^{14}$ traça as bases do Estado brasileiro, que será regido pela democracia, soberania, dignidade da pessoa humana, valores sociais do trabalho e da livre iniciativa, pluralismo político, separação de poderes, no objetivo de construir uma sociedade livre, justa e solidária, garantir o desenvolvimento nacional, erradicar a pobreza e a marginalização e reduzir as desigualdades sociais e regionais, promover o bem de todos, sem preconceitos de origem, raça, sexo, cor, idade e quaisquer outras formas de discriminação, adotando, na ordem internacional, os princípios de independência nacional, prevalência dos direitos humanos, autodeterminação dos povos e outros mais.

A interpretação correta da Constituição possibilita a compreensão das regras e princípios jurídicos constitucionais que são inspirados em valores predeterminados pela sociedade. Neste sentido José Afonso da Silva ${ }^{15}$ discorre que:

Busca-se, assim, formular uma concepção estrutural de constituição, que a considera no seu aspecto normativo, não como norma pura, mas como norma em sua conexão com a realidade social, que lhe dá o conteúdo fático e o sentido axiológico. Trata-se de um complexo, não de partes que se adicionam ou se somam, mas de elementos e membros que se enlaçam num todo unitário. O sentido jurídico de constituição não se obterá, se a apreciarmos desgarrada da totalidade da vida social, sem conexão com o conjunto da comunidade. Pois bem, certos modos de agir em sociedade transformam-se em condutas humanas valoradas historicamente e constituem-se em fundamento do existir comunitário, formando os elementos constitucionais do grupo social, que o constituinte intui e revela como preceitos normativos fundamentais: a constituição.

\footnotetext{
14 BRASIL. Constituição da República Federativa do Brasil.
}

15 SILVA, José Afonso. Curso de direito constitucional positivo. $20^{\circ}$ ed. São Paulo: Malheiros Editores, 2002, p. 39. 
BERGAMASCHI, Joice Duarte Gonçalves; AROSEMENA, Rebeca Isabel Muñoz; GOMES, Sergio Alves. A sustentabilidade como um valor. Revista Eletrônica Direito e Política, Programa de Pós-Graduação Stricto Sensu em Ciência Jurídica da UNIVALI, Itajaí, v.13, n.3, $3^{\circ}$ quadrimestre de 2018. Disponível em: www.univali.br/direitoepolitica - ISSN 1980-7791

Os valores da comunidade são salvaguardados por normas jurídicas, reguladas, em primeiro lugar, pela Constituição, razão pela qual o sentido do texto constitucional não pode ser considerado em separado da realidade social. Por conta disso, diz-se que os valores dispostos na Carta Maior são munidos de concretude, - que legitima a busca pela plena efetividade de suas disposições na contemporaneidade.

\subsection{A EFETIVIDADE DOS VALORES CONSTITUCIONAIS}

Partindo da ideia de que as normas jurídicas que protegem os valores mais importantes da sociedade são inseridas nos textos constitucionais como princípios, oportuno se faz discorrer sobre a diferença entre regras e princípios, sua aplicabilidade e sua conexão com a chamada "jurisprudência dos valores".

Segundo Robert Alexy ${ }^{16}$, aquele que indica que algo tem valor realiza uma valoração, cujos conceitos são agrupados nos juízos classificatório, comparativo e métrico. Para o Autor, o juízo classificatório envolve a indicação de um valor positivo, negativo ou neutro; o juízo comparativo dá ao objeto valor maior ou igual a outro e; o juízo métrico aponta para a magnitude do que está sendo considerado.

Para Robert Alexy ${ }^{17}$, as valorações baseiam-se, então, em diversos critérios que, concorrentes entre si, necessitam de sopesamento, já que correspondem à aplicação de princípios, sendo este o principal contraponto em relação à aplicação das regras, para as quais não é necessário realizar o procedimento de sopesar, já que, dentro desta concepção, o conflito de regras se resolve na dimensão da "validade", enquanto a colisão de princípios se resolve na dimensão do "valor"18.

Assim, havendo colisão entre duas normas decorrente da constatação de que a aplicação independente de cada uma delas conduz a dois juízos contraditórios entre si, em se tratando de normas provenientes de regras, o conflito será resolvido de modo que uma delas valerá e sua consequência jurídica será

16 ALEXY, Robert. Teoria dos direitos fundamentais. Tradução de Virgílio Afonso da Silva. $2^{a}$ Edição, 4a tiragem. São Paulo: Malheiros Editores, 2015, p. 147-149.

17 ALEXY, Robert. Teoria dos direitos fundamentais, p. 150.

18 BONAVIDES, Paulo. Curso de Direito constitucional, p. 279. 
BERGAMASCHI, Joice Duarte Gonçalves; AROSEMENA, Rebeca Isabel Muñoz; GOMES, Sergio Alves. A sustentabilidade como um valor. Revista Eletrônica Direito e Política, Programa de Pós-Graduação Stricto Sensu em Ciência Jurídica da UNIVALI, Itajaí, v.13, n.3, 30 quadrimestre de 2018. Disponível em: www.univali.br/direitoepolitica - ISSN 1980-7791

obrigatória, enquanto a outra não será válida e não poderá ser aplicada. Entretanto, em se tratando de conflito de normas provenientes de princípios, embora igualmente importantes, uma delas deverá recuar sob uma cláusula de exceção que dentro dela se introduza, pois, de acordo com o caso concreto, os princípios têm "peso" diferente e o princípio de maior peso prepondera ${ }^{19}$.

Neste sentido, Paulo Bonavides ${ }^{20}$ sustenta que o posicionamento de Robert Alexy traz um ponto de entrelaçamento entre a teoria dos princípios e a teoria dos valores, pois aquela se encontra subjacente a esta numa dinâmica em que se "[...] as regras tem que ver com a validade, os princípios têm muito que ver com os valores". Assim, o posicionamento de Robert Alexy caminha na mesma direção da jurisprudência dos valores, no que reside a evidente contemporaneidade de seu pensamento jurídico no tocante ao valor normativo dos princípios ${ }^{21}$.

Contudo, contra o conceito de princípio formulado por Robert Alexy existem três principais objeções. A primeira delas está relacionada à possibilidade de colisões entre princípios, cuja resolução importaria na declaração de invalidade de um deles; a segunda aponta para a ocorrência de princípios absolutos, que não podem ser colocados numa relação de preferência perante outros princípios, e; a terceira indica que o conceito de princípio é demasiado amplo e importaria em tonar objeto de avaliação todos os interesses possíveis ${ }^{22}$.

Contra as referidas críticas, Paulo Bonavides ${ }^{23}$ indica os principais argumentos de defesa listados pelo próprio Robert Alexy. No tocante à invalidade dos princípios, trata-se de princípios ditos "fracos", que em nenhum caso prevaleceriam sobre os demais; em relação aos princípios absolutos, como eles têm precedência sobre todos os demais princípios, não há que se aplicar o teorema da colisão; e, por fim, no que se refere à amplitude terminológica e amparo de todos os interesses

19 BONAVIDES, Paulo. Curso de Direito constitucional. 13a Ed. São Paulo, Malheiros, 2003, p. 279-280.

20 BONAVIDES, Paulo. Curso de Direito constitucional, p. 280.

21 BONAVIDES, Paulo. Curso de Direito constitucional, p. 280.

22 BONAVIDES, Paulo. Curso de Direito constitucional, p. 280-281.

23 BONAVIDES, Paulo. Curso de Direito constitucional, p. 280-281. 
BERGAMASCHI, Joice Duarte Gonçalves; AROSEMENA, Rebeca Isabel Muñoz; GOMES, Sergio Alves. A sustentabilidade como um valor. Revista Eletrônica Direito e Política, Programa de Pós-Graduação Stricto Sensu em Ciência Jurídica da UNIVALI, Itajaí, v.13, n.3, 30 quadrimestre de 2018. Disponível em: www.univali.br/direitoepolitica - ISSN 1980-7791

possíveis, o modelo sustentado é dito "fundamentado", que não agrega definições de um enunciado de preferência como resultado de um processo psíquico não controlável racionalmente ${ }^{24}$.

Embora seja objeto de críticas, a teoria de Robert Alexy tem grande importância para o Direito, porque ressalta a importância dos princípios como mandamentos otimizadores da aplicação e efetivação dos valores fundamentais que a sociedade achou pertinente amparar por meio da própria Constituição.

Daniel Sarmento ${ }^{25}$ destaca que o movimento de criação de constituições que trazem em seu bojo o fortalecimento da jurisdição constitucional, com a instituição de fortes mecanismos para a proteção de valores fundamentais, se deu após a Segunda Guerra Mundial, a fim de evitar que maiorias políticas pudessem perpetrar a barbárie, como ocorrera no nazismo alemão.

Estas constituições "nasceram" impregnadas de elevado teor axiológico e contemplaram uma ampla variedade de temas, cuja interpretação extensiva e abrangente pelo Poder Judiciário deu origem ao fenômeno da constitucionalização da ordem jurídica, "que ampliou a influência das constituições sobre todo o ordenamento, levando à adoção de novas leituras de normas e institutos nos maios variados ramos do Direito" 26 .

Deste modo, no Estado contemporâneo, o Poder Judiciário se viu alçado a uma posição importantíssima no desenho institucional porque sérias questões passaram a ser decididas sob suas "portas", sobretudo a despeito de normas constitucionais relevantes e com grande abertura semântica. A procura por legitimidade a estas decisões, que frequentemente se utilizam da ponderação para resolver tensões entre princípios constitucionais colidentes, impulsionou o desenvolvimento de teorias que incorporam ao Direito elementos que o positivismo

\footnotetext{
${ }^{24}$ ALEXY, Robert. Teoria dos direitos fundamentais, p. 165.

25 SARMENTO, Daniel. Filosofia e teoria constitucional contemporânea. Rio de Janeiro: Lumen Juris, 2009, p. 117.

26 SARMENTO, Daniel. Filosofia e teoria constitucional contemporânea, p. 117.
} 
BERGAMASCHI, Joice Duarte Gonçalves; AROSEMENA, Rebeca Isabel Muñoz; GOMES, Sergio Alves. A sustentabilidade como um valor. Revista Eletrônica Direito e Política, Programa de Pós-Graduação Stricto Sensu em Ciência Jurídica da UNIVALI, Itajaí, v.13, n.3, 30 quadrimestre de 2018. Disponível em: www.univali.br/direitoepolitica - ISSN 1980-7791

desconsiderava, já que de natureza moral ou relacionadas ao campo empírico subjacente às normas ${ }^{27}$.

Neste cenário, argumentos ditos "neoconstitucionalistas"28 surgiram para elevar visões mais favoráveis ao ativismo judicial em defesa dos valores constitucionais:

No lugar de concepções estritamente majoritárias do princípio democrático, são endossadas teorias de democracia mais substantivas, que legitimam amplas restrições aos poderes do legislador em nome dos direitos fundamentais e da proteção das minorias, e possibilitem a sua fiscalização por juízes não eleitos. E ao invés de uma teoria das fontes do Direito focada no Código e na lei formal, enfatiza-se a centralidade da Constituição no ordenamento, a ubiquidade de sua influência na ordem jurídica e o papel criativo da jurisprudência ${ }^{29}$.

É dentro desta ideia de compreensão e aplicação de valores morais pela ordem constitucional que Daniel Sarmento ${ }^{30}$ indica haver espaço para visões comunitaristas, que buscam na moralidade positiva e nas pré-compreensões socialmente vigentes o norte para a hermenêutica constitucional e inclui na seara interpretativa os valores e cosmovisões hegemônicas na sociedade.

A recepção do neoconstitucionalismo no Brasil se deu após a promulgação da Constituição Federal de 1988, que desencadeou, num primeiro momento, um constitucionalismo da efetividade, cujos autores, como Luis Roberto Barroso e Clèmerson Merlin Clève, defenderam a tese de que a Constituição é norma jurídica e, por isso, deveria ser rotineiramente aplicada pelos juízes, para promover justiça, igualdade e liberdade. Num segundo momento, autores como Paulo Bonavides e Eros Roberto Grau passaram a divulgar a teoria dos princípios de Robert Alexy e também Ronald Dworkin, fomentando discussões sobre a ponderação de

\footnotetext{
27 SARMENTO, Daniel. Filosofia e teoria constitucional contemporânea, p. 118.

28 Segundo Daniel Sarmento, o Neoconstitucionalismo é um movimento que comporta diversas visões sobre o fenômeno jurídico na contemporaneidade, com juristas que se filiam a linhas bastante heterogêneas, como Ronald Dworkin, Robert Alexy, Peter Harbele, Gustavo Zagrebelsky, Luigi Ferrajoli e Carlos Santiado, e que busca construir novas grades teóricas em substituição àquelas do positivismo tradicional, consideradas incompatíveis com a nova realidade. In: Filosofia e teoria constitucional contemporânea, p. 115-119.
}

29 SARMENTO, Daniel. Filosofia e teoria constitucional contemporânea, p. 121-122.

30 SARMENTO, Daniel. Filosofia e teoria constitucional contemporânea, p. 122. 
BERGAMASCHI, Joice Duarte Gonçalves; AROSEMENA, Rebeca Isabel Muñoz; GOMES, Sergio Alves. A sustentabilidade como um valor. Revista Eletrônica Direito e Política, Programa de Pós-Graduação Stricto Sensu em Ciência Jurídica da UNIVALI, Itajaí, v.13, n.3, $3^{\circ}$ quadrimestre de 2018. Disponível em: www.univali.br/direitoepolitica - ISSN 1980-7791

interesses, o princípio da proporcionalidade e a eficácia dos direitos fundamentais ${ }^{31}$.

Nesta nova fase de discussões sobre a jurisdição constitucional, Daniel Sarmento ${ }^{32}$ destaca que o neoconstitucionalismo no Brasil se identifica com a posição substancialista, "que compartilha com ele a crença numa ampla legitimidade do ativismo judicial em favor dos valores constitucionais". Aqui, é possível citar como exemplos a alteração do posicionamento do Supremo Tribunal Federal (STF) em relação aos direitos sociais, que, antes tidos como "normas programáticas", passaram a ter imensa proteção judicial; o reconhecimento da eficácia horizontal dos direitos fundamentais, e; a progressiva superação da visão kelseniana da jurisdição constitucional, que a equiparava a "legislador negativo", mas passou a admitir técnicas mais heterodoxas, como as declarações de inconstitucionalidade sem pronúncia de nulidade e as sentenças aditivas ${ }^{33}$.

Assim, vislumbra-se que a jurisprudência nacional, sobretudo no STF, tem invocado cada vez mais em seus julgamentos princípios abertos, a ponderação de interesses, a proporcionalidade e referências filosóficas em suas decisões, o que dá ao Poder Judiciário papel de destaque na agenda de implementação às inovações e aos valores consubstanciados na Constituição Federal de $1998^{34}$.

Os novos posicionamentos ainda revelam uma tendência que conduz a valoração e eficácia dos princípios como "normas-chave" de todo o sistema jurídico, contemplando a Constituição como uma ordem concreta de valores, cuja efetividade pode ser outorgada pelo Poder Judiciário sem necessidade de mediações.

\footnotetext{
31 SARMENTO, Daniel. Filosofia e teoria constitucional contemporânea, p. 125-126.

32 SARMENTO, Daniel. Filosofia e teoria constitucional contemporânea, p. 128.

33 SARMENTO, Daniel. Filosofia e teoria constitucional contemporânea, p. 130.

34 SARMENTO, Daniel. Filosofia e teoria constitucional contemporânea, p. 129.
} 
BERGAMASCHI, Joice Duarte Gonçalves; AROSEMENA, Rebeca Isabel Muñoz; GOMES, Sergio Alves. A sustentabilidade como um valor. Revista Eletrônica Direito e Política, Programa de Pós-Graduação Stricto Sensu em Ciência Jurídica da UNIVALI, Itajaí, v.13, n.3, $3^{\circ}$ quadrimestre de 2018. Disponível em: www.univali.br/direitoepolitica - ISSN 1980-7791

\section{O SER HUMANO E SUA RELAÇÃO COM A NATUREZA}

As teorias que representam a relação entre o homem e a natureza ganham enorme importância na atualidade. Com efeito, a relação entre o homem e a natureza sempre vai ter certo grau de diferença, haja vista que a natureza sempre poderá manter-se sem o homem, mas o homem jamais poderá sobreviver sem o respaldo do meio ambiente natural.

Não obstante, os graves danos que vêm acontecendo ao meio ambiente em nível mundial colocam a questão ecológica no centro das atenções em múltiplas áreas do conhecimento e, de modo especial, no âmbito do Direito, como bem indica Sergio Alves Gomes ${ }^{35}$. A atuação dos juristas é de suma relevância para a eficácia e a proteção dos valores ambientais, bem como outros mais relacionados à promoção da sustentabilidade.

Com efeito, são os valores humanos que determinam a relação entre o homem e a natureza, cabendo à Ética o esclarecimento do tema.

De acordo com Antônio Silveira Ribeiro dos Santos ${ }^{36}$, no artigo "O Homem e a Natureza", a ética:

É a forma de proceder ou de se comportar o ser humano no seu meu social, sendo, portanto, uma relação intersocial do homem. Os parâmetros são as condutas aceitas no meio social, e tem raízes no fato da moral como sistema de regulamentação das relações intersociais humanas, e se assenta em um modo de comportamento.

Portanto, a ética determina o comportamento social do indivíduo e tem como parâmetro as condutas aceitas pela sociedade em que ele vive. Deste modo, observa-se que o comportamento de cada pessoa terá por objetivo produzir uma

\footnotetext{
35 GOMES, Sergio Alves. Hermenêutica constitucional: um contributo à construção do estado democrático de direito, p. 168-169.

${ }^{36}$ RIBEIRO DOS SANTOS, Antônio Silveira. Homem-natureza: a nova relação ética. In: Tribuna S. Carlos-SP - 12.05.96; - JBA -Gr. Jornal. Ronaldo Cortês-SP- 19.07.96; Revista Meio Ambiente Industrial. SP- jan. / Fev. 1998 (variação com o título "Ética ambiental: novo paradigma industrial").
} 
BERGAMASCHI, Joice Duarte Gonçalves; AROSEMENA, Rebeca Isabel Muñoz; GOMES, Sergio Alves. A sustentabilidade como um valor. Revista Eletrônica Direito e Política, Programa de Pós-Graduação Stricto Sensu em Ciência Jurídica da UNIVALI, Itajaí, v.13, n.3, $3^{\circ}$ quadrimestre de 2018. Disponível em: www.univali.br/direitoepolitica - ISSN 1980-7791

consequência, baseada no "ethos", nos hábitos da sociedade e em benefício dela, com base na dignidade de cada uma delas.

O meio ambiente é um bem de suprema importância à vida digna. Mais, viver num meio ambiente sadio e ecologicamente equilibrado é direito fundamental, que tem apoio no princípio da dignidade da pessoa humana. Neste sentido, destaca Édis Milaré $^{37}$ :

O reconhecimento do direito a um meio ambiente sadio configura-se, na verdade, como extensão do direito à vida, quer sob o enfoque da própria existência física e saúde dos seres humanos, quer sob o enfoque da dignidade desta existência - a qualidade de vida -, que faz com que valha a pena viver.

A dignidade é fundamento estruturante do Estado brasileiro (artigo 10, inciso III) ${ }^{38}$ e é qualidade intrínseca da pessoa humana. Assim, proteger o meio em que as pessoas vivem e dar elas a possibilidade de viver com qualidade é algo intrínseco à plenitude da sociedade. Por esta razão, a Constituição Federal do Brasil de 1988 trouxe a tutela do meio ambiente, com expressa ligação à promoção de vida sadia a todos, no corpo de seu artigo $225^{39}$ :

Art. 225. Todos têm direito ao meio ambiente ecologicamente equilibrado, bem de uso comum do povo e essencial à sadia qualidade de vida, impondo-se ao Poder Público e a coletividade o dever de defendê-lo e de preservá-lo para as presentes e futuras gerações.

As premissas protetivas enunciadas no artigo 225 da Constituição Federal não se encontram isoladas, pois ainda são reforçadas por outras normativas espalhadas pelo corpo constitucional, dentre as quais se destacam o artigo 50, LXXIII, que dispõe sobre a possibilidade de propositura de ação popular diante da prática de ato lesivo ao meio ambiente e o artigo 170, VI, que coloca a defesa do meio ambiente como um dos princípios regedores da ordem econômica ${ }^{40}$.

\footnotetext{
37 MILARÉ, Édis. Direito do ambiente. 9. ed. São Paulo: Revista dos Tribunais, 2014, p. 137.

38 BRASIL. Constituição da República Federativa do Brasil de 1988.

39 BRASIL. Constituição da República Federativa do Brasil de 1988.

40 BRASIL. Constituição da República Federativa do Brasil de 1988.
} 
BERGAMASCHI, Joice Duarte Gonçalves; AROSEMENA, Rebeca Isabel Muñoz; GOMES, Sergio Alves. A sustentabilidade como um valor. Revista Eletrônica Direito e Política, Programa de Pós-Graduação Stricto Sensu em Ciência Jurídica da UNIVALI, Itajaí, v.13, n.3, $3^{\circ}$ quadrimestre de 2018. Disponível em: www.univali.br/direitoepolitica - ISSN 1980-7791

Este tratamento constitucional, que atrela a temática ambiental à promoção de plena qualidade de vida, sinaliza uma tendência das constituições contemporâneas de primar pela consagração de valores que, muito além do aspecto provedor econômico, contêm dispositivos relacionados ao próprio bem-estar das pessoas. 0 novo cenário, por conseguinte, não apenas deu uma nova roupagem à produção legislativa, mas principalmente, à atuação do Poder Judiciário, que passou a apreciar conflitos cujo deslinde importa em verdadeira concessão de efetividade aos mandamentos constitucionais consagrados na Carta de 1988.

Assim, constatando-se que o direito ao meio ambiente sadio é extensão do próprio direito à vida, é preciso dar ênfase a medidas que deem efetividade a tal mandamento. Sergio Alves Gomes ${ }^{41}$ indica que aos juristas incumbe a defesa dos bens vitais da natureza, na medida em que a perspectiva ecológica é mais que o aprendizado de leis alusivas à proteção do meio ambiente, pois consiste na inclusão participativa à formação de um "ethos" mundial em defesa do sistema ecológico que possibilita a vida no planeta, pois catástrofes ambientais como terremotos, furacões e novas doenças, são fatos indicativos de consequências da ação humana depredadora da natureza.

Com efeito, se ultimamente os valores ambientais tem sido afetados por crises ambientais e falta de controle sobre o uso de recursos naturais, considera-se, que a conexão "objetivos-valores-ações" determinará a correta utilização e proteção do meio ambiente natural, pois, conforme discorre François Ost"2, "uma coisa é certa: a responsabilidade em relação às gerações futuras e a elaboração de um patrimônio natural comum, começam aqui e agora. Eles não têm outro advogado de defesa que não o cidadão, o utilizador e o consumidor que nós somos".

A falta de controle sobre o bom uso dos recursos disponíveis não pode ser resolvida senão por aqueles que deles fazem o uso. O que pode resolver a questão

41 GOMES, Sergio Alves. Hermenêutica constitucional: um contributo à construção do estado democrático de direito, p. 170.

42 OST, François. A natureza à margem da lei: a ecologia à prova do direito. Lisboa: Instituto Piaget, 1997, p. 395. 
BERGAMASCHI, Joice Duarte Gonçalves; AROSEMENA, Rebeca Isabel Muñoz; GOMES, Sergio Alves. A sustentabilidade como um valor. Revista Eletrônica Direito e Política, Programa de Pós-Graduação Stricto Sensu em Ciência Jurídica da UNIVALI, Itajaí, v.13, n.3, 30 quadrimestre de 2018. Disponível em: www.univali.br/direitoepolitica - ISSN 1980-7791

ambiental, como bem esclarece François Ost 43 "é o debate democrático, agora interpelado pela urgência de desafios inéditos, que deverão proceder às decisões suscetíveis de infletir na nossa forma de habitar a terra." Com efeito, senão pelo debate e discussão sobre os valores que sejam realmente importantes à vida humana com qualidade, não haverá outra solução para o destino do meio ambiente que não a sua destruição.

Não obstante, o meio ambiente natural é o maior patrimônio dos habitantes da Terra e, como bem assinala Édis Milaré44, "Defender esse patrimônio constitui tarefa ingente e obrigatória da humanidade, como fator de sua própria sobrevivência", no interesse das presentes e futuras gerações. Há, então, não apenas um preceito jurídico, mas também uma obrigação ética de solidariedade da espécie humana em relação à natureza.

Para Gregorio Robles 45 "uma crise de valores envolve diretamente a atenuação do sentimento de obrigatoriedade em nossa forma de conviver e, paralelamente, a inflação da atitude reivindicatória". Isto quer dizer que, é necessário que a sociedade comece a perceber que as coisas têm que ser feitas não por obrigação, mas sim com responsabilidade; a sociedade tem que ter a consciência de que está conectada com o mundo e com tudo ${ }^{46}$.

A sociedade precisa reconhecer que é responsável por suas ações que, infelizmente, são a grande causa de parte dos problemas atuais. Senão, vejamos:

A questão ambiental está intimamente relacionada com o modo de como a sociedade se relaciona com a natureza. Nessas estão implicadas as relações sociais e as complexas relações entre o mundo físico-químico e o mundo orgânico. A dificuldade dessas relações se encontra no fato de que o

\footnotetext{
43 OST, François. A natureza à margem da lei: a ecologia à prova do direito, p. 395.
}

44 MILARÉ, Édis. Direito do ambiente, p. 223.

45 ROBLES, Gregorio. Os direitos fundamentais e a ética na sociedade atual. São Paulo: Civitas, 1995, p. 84.

46 BIZAWU, Kiwonghi; ROCHA, Marcelo Antonio. Meio ambiente e fundamentos ético-morais e filosóficos: o despertar da conscientização ecológica. In: Direito ambiental e socioambientalismo [Recurso eletrônico on-line]. Coord.: Carlos Frederico Marés Filho, Livia Gaigher Bosio Campello, Norma Sueli Padilha - Florianópolis: CONPEDI, 2015. Disponivel em: https://www.conpedi.org.br/publicacoes/c178h0tg/gb7cf8t2/B6fIPDgl425464D8.pdf. Acesso em 05 de maio de 2018 , p. 475. 
BERGAMASCHI, Joice Duarte Gonçalves; AROSEMENA, Rebeca Isabel Muñoz; GOMES, Sergio Alves. A sustentabilidade como um valor. Revista Eletrônica Direito e Política, Programa de Pós-Graduação Stricto Sensu em Ciência Jurídica da UNIVALI, Itajaí, v.13, n.3, $3^{\circ}$ quadrimestre de 2018. Disponível em: www.univali.br/direitoepolitica - ISSN 1980-7791

pensamento prevalente e herdado afirma que a sociedade e a natureza são termos que se excluem. Todavia, o que não se teve a capacidade de observar é que a sociedade estaria destruindo as fontes vitais à sua própria existência ${ }^{47}$.

Com efeito, as regras de comportamento humano devem promover a proteção do indivíduo e do meio em que ele vive, mas é o agir humano, individualizado, que determina a proteção da coletividade. Daí a importância de promover comportamentos que se afigurem sustentáveis.

Não é um fato oculto que muitas vezes as necessidades humanas são priorizadas e o cuidado e a proteção para com o meio ambiente não são considerados, o que talvez, em casos excepcionais e limitados, possa não significar prejuízos. Mas quando atividades insustentáveis são constantemente realizadas sem pensar nas consequências nocivas que poderão ser produzidas, não é só o meio ambiente que restará por prejudicado, mas o bem-estar de toda a vida humana.

Uma consciência ambientada na sustentabilidade que substitua a ganância como prioridade e tendo em conta o "ethos", poderá salvar a vida no planeta. Mais que proteção ambiental, a promoção da sustentabilidade ganha enorme importância porque também dirige a criação de novas políticas a serem aplicadas dentro do ordenamento jurídico de um país, de modo a permitir crescimento econômico com qualidade de vida.

\section{AS DIMENSÕES DA SUSTENTABILIDADE}

O termo sustentabilidade quase sempre está associado ao desenvolvimento de práticas que revelem respeito ao meio ambiente. Contudo, contemporaneamente, a sustentabilidade está associada a consideração de valores que reflitam a proteção de uma série de elementos que hão de ser levados em conta para refletir qualidade de vida às sociedades, com o levante de perspectivas que revelem a proteção do meio ambiente ecológico, social, econômico, ético e jurídico-político.

\footnotetext{
47 BALIM, Ana Paula Cabral. MOTA, Luiza Rosso; SILVA, Maria Beatriz Oliveira da. Complexidade ambiental: o repensar da relação Homem-Natureza e seus desafios na sociedade contemporânea. Revista Veredas do Direito. Belo Horizonte, v. 11, n. 21, p. 163-186, 2014, p. 170.
} 
BERGAMASCHI, Joice Duarte Gonçalves; AROSEMENA, Rebeca Isabel Muñoz; GOMES, Sergio Alves. A sustentabilidade como um valor. Revista Eletrônica Direito e Política, Programa de Pós-Graduação Stricto Sensu em Ciência Jurídica da UNIVALI, Itajaí, v.13, n.3, 30 quadrimestre de 2018. Disponível em: www.univali.br/direitoepolitica - ISSN 1980-7791

José Eli da Veiga ${ }^{48}$ discorre que até o final dos anos 70 do Século XX o adjetivo "sustentável" não passava de um jargão técnico usado por algumas comunidades científicas para evocar a possibilidade de um ecossistema não perder sua resiliência mesmo estando sujeito à ação humana recorrente. Nos anos 90, sobretudo a partir da realização da ECO Rio 92, sobre meio ambiente e desenvolvimento humano, o termo sustentabilidade passou a ser visto com receio, já que crescia a ideia de que deveria adjetivar o crescimento econômico, para que significasse mais que elevação do PIB (Produto Interno Bruto) dos países, de modo que traduzisse o lucro também em benefícios sociais.

A partir de então, reivindicações por uma sociedade mundial que prezasse pelo crescimento sustentável passaram a ter mais voz, ante o vislumbre da necessidade de proteção para promoção de qualidade à vida de todos os seres humanos. Vejamos:

O desenvolvimento sustentável engloba mais que crescimento econômico e proteção ambiental, ele é calcado também na ideia de equidade social e bem-estar, que constitui o seu terceiro pilar. Já foi reconhecido que tanto a pobreza como a riqueza extremas pressionam o meio ambiente. Portanto, ao se falar em desenvolvimento sustentável, deve-se considerar também o desenvolvimento social, afinal, é plenamente possível que o crescimento econômico coexista com a pobreza disseminada. Ademais, com o desenvolvimento social as pressões sobre o meio ambiente diminuem, na medida em que o uso sustentável dos recursos naturais auxilia a realização da equidade social ${ }^{49}$.

Portanto, um desenvolvimento que se possa chamar de sustentável deve abranger a proteção ambiental e outras dimensões que signifiquem equidade e bem-estar social, pois tanto a riqueza quanto pobreza podem figurar elementos que elevam a pressão sobre o meio ambiente humano.

\footnotetext{
48 VEIGA, José Eli da. Sustentabilidade: a legitimação de um novo valor. São Paulo: Editora Senac São Paulo, 2010, p. 11.

49 TÁRREGA, Maria Cristina. V. B.; PÉREZ, H. L. A. A tutela jurídica da biodiversidade: a influência da convenção sobre a diversidade biológica no sistema internacional de patentes. In: Meio Ambiente e Desenvolvimento Sustentável. Org. TARREGA, Maria Cristina V. B. B. São Paulo: RCS Editora, 2007, p. 21.
} 
BERGAMASCHI, Joice Duarte Gonçalves; AROSEMENA, Rebeca Isabel Muñoz; GOMES, Sergio Alves. A sustentabilidade como um valor. Revista Eletrônica Direito e Política, Programa de Pós-Graduação Stricto Sensu em Ciência Jurídica da UNIVALI, Itajaí, v.13, n.3, 30 quadrimestre de 2018. Disponível em: www.univali.br/direitoepolitica - ISSN 1980-7791

O direito ao meio ambiente sadio e equilibrado previsto no artigo 225 da Constituição Federal $^{50}$ envolve muito mais que proteção ecológica, pois é "princípio-valor" constitucional que impera sejam adotadas políticas que busquem a plenitude de vida aos seres humanos.

Juarez Freitas ${ }^{51}$ discorre que o mandamento do artigo 225 da Constituição Federal do Brasil de 1988, que dispõe que todos têm direito ao meio ambiente ecologicamente equilibrado, é princípio cogente da sustentabilidade multidimensional, que irradia efeitos e gera novas e incontornáveis obrigações para todas as províncias do Direito, não apenas para o Direito Ambiental, porque apenas uma natureza multidimensional, que também leve em conta componentes éticos, sociais, econômicos e jurídico-políticos, é capaz de dar real efetividade ao direito dos indivíduos de viver em um meio ambiente que realmente traduza bemestar social.

Para Juarez Freitas ${ }^{52}$ a sustentabilidade traduz-se como dever fundamental de, a longo prazo, produzir e partilhar o desenvolvimento limpo e propício à saúde, abrangendo componentes éticos, sociais, ambientais, econômicos e jurídicopolíticos. E deste princípio fundamental decorrem relevantes obrigações: de preservar a vida em sua diversidade, coibida toda forma de crueldade; de antecipar, prevenir e precaver no exercício regular do poder de polícia administrativa; de responder pelo ciclo de produção e circulação de produtos e serviços, bem como contribuir para o consumo esclarecido, o trabalho decente e o acesso a moradias e transportes razoáveis; de acolher o caráter preferencial de energias renováveis; de sopesar os custos e benefícios diretos e indiretos de todos os projetos; de intervir ativamente no sentido de promover a justiça ambiental ${ }^{53}$.

A dimensão ambiental da sustentabilidade alude ao direito das gerações atuais, sem prejuízo das futuras, ao ambiente limpo em todos os aspectos. Assim, a dimensão ambiental da sustentabilidade suscita que não pode haver qualidade de

\footnotetext{
50 BRASIL. Constituição da República Federativa do Brasil de 1988.

51 FREITAS, Juarez. Sustentabilidade: direito ao futuro, p. 40-41.

52 FREITAS, Juarez. Sustentabilidade: direito ao futuro, p. 40.

53 FREITAS, Juarez. Sustentabilidade: direito ao futuro, p. 40.
} 
BERGAMASCHI, Joice Duarte Gonçalves; AROSEMENA, Rebeca Isabel Muñoz; GOMES, Sergio Alves. A sustentabilidade como um valor. Revista Eletrônica Direito e Política, Programa de Pós-Graduação Stricto Sensu em Ciência Jurídica da UNIVALI, Itajaí, v.13, n.3, 30 quadrimestre de 2018. Disponível em: www.univali.br/direitoepolitica - ISSN 1980-7791

vida e longevidade digna em um ambiente degradado, bem como não pode haver vida sem zelo da sustentabilidade ambiental em tempo útil ${ }^{54}$. Deste modo, ou se protege a qualidade ambiental ou não haverá futuro para a espécie humana.

A dimensão social da sustentabilidade diz respeito a não se admitir o modelo do desenvolvimento excludente e iníquo, pelo que não se admite a discriminação negativa, uma vez que seriam válidas apenas as distinções voltadas a auxiliar os desfavorecidos, mediante ações positivas e compensações que permitam fazer frente à pobreza medida por padrões confiáveis, que levem em conta a gravidade das questões ambientais ${ }^{55}$. A sustentabilidade aqui estaria relacionada ao respeito ao próximo na sua condição de indivíduo sujeito de direitos e merecedor de respeito, para preservação de sua dignidade e pleno exercício de sua personalidade.

Já a dimensão ética da sustentabilidade está relacionada ao sentido de que todos os seres têm uma ligação intersubjetiva e natural, donde impera o dever universal de deixar um legado positivo na face da terra ${ }^{56}$. Aqui, a cooperação entre indivíduos impera para possibilitar a continuidade da vida no planeta, que é a casa de todos os seres, humanos, vegetais ou animais. E o ser humano é responsável pela preservação de tudo o que existe, pelo bem de sua própria espécie e de todas as outras que habitam a Terra.

A dimensão econômica da sustentabilidade evoca a ponderação entre eficiência e equidade, ou seja, um sopesamento entre benefícios e custos diretos e indiretos ${ }^{57}$. A natureza não pode ser vista como simples capital e a regulação estatal se faz impositiva para coibir os desvios comuns dos adeptos do fundamentalismo voraz de mercado, que ignoram a complexidade do mundo natural ${ }^{58}$. Com efeito, a falta

\footnotetext{
54 FREITAS, Juarez. Sustentabilidade: direito ao futuro, p. 64-65.

55 FREITAS, Juarez. Sustentabilidade: direito ao futuro, p. 58.

56 FREITAS, Juarez. Sustentabilidade: direito ao futuro, p. 60.

57 FREITAS, Juarez. Sustentabilidade: direito ao futuro, p. 65.

58 FREITAS, Juarez. Sustentabilidade: direito ao futuro, p. 66.
} 
BERGAMASCHI, Joice Duarte Gonçalves; AROSEMENA, Rebeca Isabel Muñoz; GOMES, Sergio Alves. A sustentabilidade como um valor. Revista Eletrônica Direito e Política, Programa de Pós-Graduação Stricto Sensu em Ciência Jurídica da UNIVALI, Itajaí, v.13, n.3, 30 quadrimestre de 2018. Disponível em: www.univali.br/direitoepolitica - ISSN 1980-7791

de cuidado regulatório por parte dos Estados pode tornar inviável perseguir um crescimento que se traduza em desenvolvimento sustentável.

A dimensão jurídico-política da sustentabilidade ecoa no sentido de determinar a eficácia direta e imediata, independente de regulamentação, do direito ao futuro e, assim, apresenta-se como dever constitucional oferecer proteção à liberdade de cada cidadão no processo de estipulação intersubjetiva do conteúdo intertemporal dos direitos e deveres fundamentais das gerações presentes e futuras, sempre que viável, diretamente ${ }^{59}$. Com efeito, é a dimensão jurídico-política que efetiva as demais dimensões da sustentabilidade, já que o poder Judiciário pode realizar a implementação dos direitos constitucionais que estão relacionados ao desenvolvimento sustentável.

Segundo Juarez Freitas ${ }^{60}$ as dimensões ética, jurídico-políticas, ambiental, social e econômica se entrelaçam e se constituem mutuamente, numa dialética da sustentabilidade que não pode ser rompida. Neste sentido, a multidimensionalidade deriva de uma propriedade natural de difícil refutação: o inter-relacionamento de tudo, a conexão inevitável entre seres e coisas, onde a realização ou não de uma dimensão influencia diretamente a outra61. Todas as dimensões citadas pelo Autor estão diretamente relacionadas ao pleno bem-estar dos indivíduos na sociedade, de modo que o usufruto do meio ambiente em que vivem hoje não prejudique o mesmo desfrute pelas gerações futuras.

Jared Diamond ${ }^{62}$ aduz que o avanço rápido da não-sustentabilidade demanda que os problemas ambientais sejam resolvidos no tempo da vida de crianças e adultos de agora, de modo agradável, por meio de boas escolhas, ou desagradável sob o advento de guerras, genocídio, fome, doenças epidêmicas e colapso de sociedades. O meio ambiente equilibrado necessita de cuidado no presente, com urgência, pois as ações de hoje é que decidirão como será o futuro das sociedades humanas do

\footnotetext{
59 FREITAS, Juarez. Sustentabilidade: direito ao futuro, p. 67.

60 FREITAS, Juarez. Sustentabilidade: direito ao futuro, p. 71.

61 FREITAS, Juarez. Sustentabilidade: direito ao futuro, p. 72.

62 DIAMOND, Jared. Colapso: como as sociedades escolhem o fracasso ou o sucesso. Rio de Janeiro: Record, 2005, p. 596.
} 
BERGAMASCHI, Joice Duarte Gonçalves; AROSEMENA, Rebeca Isabel Muñoz; GOMES, Sergio Alves. A sustentabilidade como um valor. Revista Eletrônica Direito e Política, Programa de Pós-Graduação Stricto Sensu em Ciência Jurídica da UNIVALI, Itajaí, v.13, n.3, $3^{\circ}$ quadrimestre de 2018. Disponível em: www.univali.br/direitoepolitica - ISSN 1980-7791

amanhã. E de nada adianta esconder-se desta urgência sob o manto de falsos argumentos, como o de que o ambiente deve ser equilibrado de acordo com a economia ou que a tecnologia do futuro resolverá os problemas causados pelas ações insustentáveis de agora.

Ora, a sustentabilidade é que deve adjetivar, condicionar e infundir as suas características ao desenvolvimento, nunca o contrário ${ }^{63}$. Com efeito, exige-se dos países muito mais que buscar o crescimento econômico, porque a sustentabilidade é diretriz a toda a atividade estatal, que tem o dever de ditar políticas de regulação do mercado de modo que fins sociais de sustentabilidade sejam atingidos.

E beira à inocência acreditar que a tecnologia do futuro funcionaria para resolver os problemas existentes e deixaria de criar novos problemas. Com efeito, soluções tecnológicas para estancar problemas geralmente são mais dispendiosas do que a adoção de medidas preventivas. E não se pode olvidar da constatação de que os problemas ambientais atuais são consequências negativas não intencionais da própria tecnologia existente, pois os rápidos avanços tecnológicos do Século XX criaram problemas novos e difíceis mais rapidamente do que resolvidos os antigos $^{64}$.

Com efeito, a sustentabilidade com análise multidimensional significa atrelar às ações humanas e, principalmente, às políticas estatais, o ideal de perseguição do bem-estar social para as atuais e futuras gerações. Significa analisar um empreendimento de mercado além de suas vantagens econômicas, a fim de verificar qual a sua contribuição para a realização do verdadeiro desenvolvimento daquela sociedade, em termos éticos, ambientais, sociais, econômicos e jurídicopolíticos.

Não é sem motivo que a compatibilização entre desenvolvimento e sustentabilidade constitui o maior desafio das políticas governamentais contemporâneas. E a intervenção estatal é a maior responsável pela promoção de interação entre estes ideais, o que não significa condicionar o ser humano ao meio

\footnotetext{
${ }^{63}$ FREITAS, Juarez. Sustentabilidade: direito ao futuro, p. 54.

${ }^{64}$ DIAMOND, Jared. Colapso: como as sociedades escolhem o fracasso ou o sucesso, p. 603.
} 
BERGAMASCHI, Joice Duarte Gonçalves; AROSEMENA, Rebeca Isabel Muñoz; GOMES, Sergio Alves. A sustentabilidade como um valor. Revista Eletrônica Direito e Política, Programa de Pós-Graduação Stricto Sensu em Ciência Jurídica da UNIVALI, Itajaí, v.13, n.3, $3^{\circ}$ quadrimestre de 2018. Disponível em: www.univali.br/direitoepolitica - ISSN 1980-7791

ambiente, mas proteger o espaço em que ele vive como direito fundamental ligado à sua própria existência. Uma sociedade sustentável protege e promove direitos de modo a propiciar o pleno desenvolvimento dos indivíduos, que deverão viver em harmonia com o meio ambiente e com os demais seres vivos.

\section{A SUSTENTABILIDADE COMO UM VALOR}

O avanço das forças econômicas, desde épocas antigas, exerce grande pressão sobre o meio ambiente humano, que acaba perecendo ante os objetivos de lucro a qualquer custo. O fenômeno da globalização dos mercados, grandemente intensificado a partir da década de 60 do Século XX, sobretudo por conta da revolução tecnológica que atingiu os meios de produção, suscitou questionamentos a partir dos setores sociais a respeito de qual seria o futuro da humanidade diante da propagação tão intensa de valores de destruição. E assim, em respeito a vida no planeta, quais valores merecem prosperar e quais devem ser alijados?

Sergio Alves Gomes ${ }^{65}$ suscita que apenas uma consciência ecológica c que substitua a ganância poderá salvar a vida no planeta, porque a Terra encontra-se no limite de sua autossustentabilidade e isso representa um grande desafio aos governos, povos e nações, acostumados a ter um sistema de vida artificial, consumista, capitalista e neoliberal, fora de sintonia com os limites impostos pela natureza e pelo senso de razoabilidade. Entretanto, o antropocentrismo excessivo e a dificuldade de implementar políticas que propiciem o desenvolvimento duradouro configuram grande entrave a efetivação da sustentabilidade.

Ainda assim, Jared Dimond ${ }^{66}$ aponta que há motivos para se ter esperança porque os mais sérios riscos enfrentados estão sob o alcance de controle dos seres humanos, pois, se "somos a causa dos problemas ambientais, temos controle sobre eles e podemos escolher entre parar ou não de causá-los e começar a resolvê-los, pois o futuro está em nossas mãos".

\footnotetext{
65 GOMES, Sergio Alves. Hermenêutica constitucional: um contributo à construção do estado democrático de direito, p. 170.

66 DIAMOND, Jared. Colapso: como as sociedades escolhem o fracasso ou o sucesso, p. 623.
} 
BERGAMASCHI, Joice Duarte Gonçalves; AROSEMENA, Rebeca Isabel Muñoz; GOMES, Sergio Alves. A sustentabilidade como um valor. Revista Eletrônica Direito e Política, Programa de Pós-Graduação Stricto Sensu em Ciência Jurídica da UNIVALI, Itajaí, v.13, n.3, $3^{\circ}$ quadrimestre de 2018. Disponível em: www.univali.br/direitoepolitica - ISSN 1980-7791

E para isso não é preciso melhores tecnologias, mas vontade política para aplicar as soluções já disponíveis, pois há escolhas que podem ser feitas por cada um, individualmente, como o planejamento a longo prazo e vontade de reconsiderar os antigos valores, num tempo em que os problemas se tornam perceptíveis, mas antes de tomarem proporções críticas ${ }^{67}$. Com efeito, não é porque o ritmo insustentável caminhou abertamente até agora que tem de continuar a ser assim, pois todos têm livre arbítrio para decidir a responsabilidade que terão sobre o futuro.

Outra escolha crucial envolve a coragem de tomar decisões dolorosas em relação a valores: quais devem continuar a ser mantidos e quais devem ser alijados? Escolhas difíceis são necessárias e, muitas vezes, a implementação do que deve prevalecer depende da política estatal. Evoluções sociais somente se tornam possíveis a partir da reavaliação de valores já adquiridos e, principalmente, por meio da afirmação e promoção dos valores que realmente traduzam bem-estar humano.

Conceituar a sustentabilidade como um valor é necessidade imperiosa para fazer valer os argumentos que permitem a existência humana com bem-estar no planeta. Contudo, há necessidade de se evitar a banalização da ideia, para que não careça de importância. José Eli da Veiga ${ }^{68}$ destaca que o sentido essencial de sustentabilidade como um valor reflete a responsabilidade pelas oportunidades e limites que condicionarão as vidas das próximas gerações da espécie humana, ou seja, estar-se-ia lidando, inevitavelmente, com o valor do amanhã.

Não obstante, a sustentabilidade como valor exige que o desenvolvimento de uma nação se sobreponha ao seu crescimento econômico, de modo que reflita na qualidade de vida dos indivíduos. José Eli da Veiga ${ }^{69}$ aponta que a sustentabilidade direcionou, por exemplo, a política econômica brasileira dos últimos 30 anos, e, de

\footnotetext{
67 DIAMOND, Jared. Colapso: como as sociedades escolhem o fracasso ou o sucesso, p. 623-624.

68 VEIGA, José Eli da. Sustentabilidade: a legitimação de um novo valor, p. 40-41.

69 VEIGA, José Eli da. Sustentabilidade: a legitimação de um novo valor, p. 50.
} 
BERGAMASCHI, Joice Duarte Gonçalves; AROSEMENA, Rebeca Isabel Muñoz; GOMES, Sergio Alves. A sustentabilidade como um valor. Revista Eletrônica Direito e Política, Programa de Pós-Graduação Stricto Sensu em Ciência Jurídica da UNIVALI, Itajaí, v.13, n.3, $3^{\circ}$ quadrimestre de 2018. Disponível em: www.univali.br/direitoepolitica - ISSN 1980-7791

consequência, houve muito mais desenvolvimento e muito menos crescimento. Vejamos:

Isso nada tem de paradoxal para quem sabe que 0 desenvolvimento de uma sociedade depende é da maneira como ela aproveita os benefícios de seu desempenho econômico para expandir e distribuir oportunidades de acesso a bens como liberdades cívicas, saúde, educação, emprego decente, etc. Ainda mais para quem já entendeu, também, que o desenvolvimento terá pernas curtas se a natureza for demasiadamente agredida pela expansão da economia, que é um sistema altamente dependente da conservação da biosfera ${ }^{70}$.

Deste modo, se a sustentabilidade é um valor, sobretudo porque práticas insustentáveis configuram um desvalor, impera para os Estados primarem pelo desenvolvimento em detrimento do mero crescimento econômico, de modo a qualificar os resultados econômicos por elevação do bem-estar da população envolvida. Afinal, para que serve o Estado senão para bem direcionar os indivíduos a desenvolverem suas potencialidades por meio do pleno exercício de direitos e liberdades? Por que viabilizar o crescimento econômico se os lucros não forem revertidos em distribuição de melhores oportunidades para os indivíduos que compõem a sociedade?

Com efeito, discutir o valor que é a sustentabilidade exige a humildade de assumir o caráter passageiro da existência humana; é ter esperança de que a humanidade deixe de abreviar o prazo de sua inevitável extinção se souber cuidar da biocapacidade dos ecossistemas dos quais depende ${ }^{71}$. E dar ênfase à ideia de que as nações devem buscar desenvolvimento e não apenas crescimento econômico, bem como questionar sobre formas de expansão das liberdades humanas de modo compatível com a conservação dos ecossistemas já é uma forma de elevar a sustentabilidade como um valor.

\footnotetext{
70 VEIGA, José Eli da. Sustentabilidade: a legitimação de um novo valor, p. 50.

71 VEIGA, José Eli da. Sustentabilidade: a legitimação de um novo valor, 35-36.
} 
BERGAMASCHI, Joice Duarte Gonçalves; AROSEMENA, Rebeca Isabel Muñoz; GOMES, Sergio Alves. A sustentabilidade como um valor. Revista Eletrônica Direito e Política, Programa de Pós-Graduação Stricto Sensu em Ciência Jurídica da UNIVALI, Itajaí, v.13, n.3, $3^{\circ}$ quadrimestre de 2018. Disponível em: www.univali.br/direitoepolitica - ISSN 1980-7791

Sobre os limites do crescimento econômico, Cristiane Derani ${ }^{72}$ discorre que a economia deve se voltar aos seus pressupostos sociais e abandonar qualquer pretensão por uma ciência exata, pois o que está em jogo não é só a otimização do uso privado de recursos, mas "externalidades" decorrentes do modo como esses recursos são apropriados. A política econômica defendida pela Autora deve ser muito mais abrangente, com características de uma política social, que vise empreendimentos que tenham fins qualitativos e não apenas quantitativos.

Isso porque o desenvolvimento econômico só pode ser compreendido integralmente quando expressa a garantia do desenvolvimento das expressões humanas, relacionadas à promoção da cultura, saúde, atividades individuais ou intersubjetivas que teriam por condão propiciar a felicidade ${ }^{73}$. Não obstante esta nova faceta atribuída ao desenvolvimento econômico, impera a necessidade de vinculá-lo à sustentabilidade, a fim de, por meio de um direito econômico ambiental, bem regulamentar políticas de compatibilização da atividade econômica, integradas ao uso das potencialidades humanas e do meio ambiente sem o seu perecimento.

O reordenamento jurídico que implica o reconhecimento de novos direitos envolve a legitimação, através da lei, de novas relações de poder, porque os "novos valores" e as "novas visões do mundo" que se expressam no discurso do desenvolvimento sustentável ressignificam o mundo e constroem novos sentidos existenciais $^{74}$. A reconstrução dessa nova ordem econômica com raízes sustentáveis é desafio para os dirigentes do mundo inteiro, que têm o dever de criar mecanismos que permitam a ascensão dos novos direitos que surgem a partir da importância dos valores que emergem do conceito de sustentabilidade.

Neste sentido, a jurisprudência tem papel de extrema relevância, pois não apenas possibilita a aplicação concreta das normas jurídicas, mas a plena efetividade dos valores consagrados no ordenamento jurídico por meio dos princípios. E trabalhar

\footnotetext{
72 DERANI, Cristiane. Direito Ambiental Econômico. 3. ed. São Paulo: Saraiva, 2008, p. 48.

73 DERANI, Cristiane. Direito Ambiental Econômico, p. 156.

74 LEFF, Enrique. Saber ambiental: sustentabilidade, racionalidade, complexidade, poder. Tradução de Lucia Mathilde Endlich Orth. 9. ed. Petrópolis, RJ: Vozes, 2012, p. 352.
} 
BERGAMASCHI, Joice Duarte Gonçalves; AROSEMENA, Rebeca Isabel Muñoz; GOMES, Sergio Alves. A sustentabilidade como um valor. Revista Eletrônica Direito e Política, Programa de Pós-Graduação Stricto Sensu em Ciência Jurídica da UNIVALI, Itajaí, v.13, n.3, $3^{\circ}$ quadrimestre de 2018. Disponível em: www.univali.br/direitoepolitica - ISSN 1980-7791

sob o fundamento de princípios logicamente pode incidir na colisão entre eles, principalmente quando o caso concreto envolve a discussão da promoção do crescimento econômico frente à proteção do meio ambiente.

Caso emblemático apreciado pelo Supremo Tribunal Federal (STF) refere-se à importação, pelo Brasil, de pneus usados e remoldados. Na Arguição de Descumprimento de Preceito Fundamental $\mathrm{n}^{0} 101 / \mathrm{DF}^{75}$, relatada pela ministra Cármen Lúcia e julgada em 26/04/2009, a presidência da república suscitava que várias decisões judiciais estavam sendo proferidas em contrariedade ao disposto em portarias editadas pelo Departamento de Operações de Comércio Exterior (DECEX) e pela Secretaria de Comércio Exterior (SECEX), bem como em oposição a resoluções oriundas do Conselho Nacional do Meio Ambiente (CONAMA) e outros decretos federais que, expressamente, vedavam a importação de pneus usados e remoldados.

Na mencionada ADPF, a presidência da república arguiu que a vedação trazida nos diversos documentos se justificava porque a importação de pneus reformados acelera a geração de resíduos no país importador, uma vez que pneus já submetidos a um processo de reforma não podem ser reformados uma segunda vez e que a proibição de importação à pneus usados era a única medida capaz de impedir a geração de quantidade de resíduos de pneus além do mínimo necessário para atender as necessidades do país.

Por estas razões, alegou-se que as decisões proferidas por juízes federais e Tribunais Regionais Federais que autorizavam a importação de pneus usados e remoldados descumpriam preceitos fundamentais previstos nos artigos 196 e 225 da Constituição Federal. A questão envolvia, ainda, interesses empresariais em aparente conflito com interesses coletivos relacionados ao direito à saúde e ao meio ambiente ecologicamente equilibrado.

Na conclusão deste caso, o STF reconheceu a adequação da arguição e a correta indicação dos preceitos fundamentais atingidos, a saber, o direito à saúde, o direito

${ }^{75}$ STF. Arguição de descumprimento de preceito fundamental no 101/DF. Brasil: Brasília, 2009. 
BERGAMASCHI, Joice Duarte Gonçalves; AROSEMENA, Rebeca Isabel Muñoz; GOMES, Sergio Alves. A sustentabilidade como um valor. Revista Eletrônica Direito e Política, Programa de Pós-Graduação Stricto Sensu em Ciência Jurídica da UNIVALI, Itajaí, v.13, n.3, $3^{\circ}$ quadrimestre de 2018. Disponível em: www.univali.br/direitoepolitica - ISSN 1980-7791

ao meio ambiente ecologicamente equilibrado e a busca do desenvolvimento econômico sustentável, expressamente indicando que os princípios constitucionais da livre iniciativa e da liberdade de comércio deveriam ser interpretados e aplicados em harmonia com o do desenvolvimento social saudável.

Por estes motivos, o STF decidiu que a atividade econômica não pode ser exercida em desarmonia com os princípios destinados a tornar efetiva a proteção ambiental, principalmente porque "a incolumidade do meio ambiente não pode ser comprometida por interesses empresariais nem ficar dependente de motivações de índole meramente econômica" porque a atividade econômica tem disciplina constitucional que a subordina, dentre outros princípios gerais, àquele que privilegia a defesa do meio ambiente, consoante disposto no artigo 170 , VI $(C F)^{76}$.

A conclusão desta ADPF demonstra claramente a importância da atuação do Poder Judiciário na ponderação de interesses e primazia dos valores mais importantes para a promoção do bem-estar humano.

Daí decorre a importância de se estudar, no âmbito do Direito, o desenvolvimento de uma ampla perspectiva ecológica capaz de contribuir na formação de uma consciência jurídica comprometida com a defesa do meio ambiente, capaz de dar efetividade aos instrumentos de que dispõem o Direito e a Política para fazer valer os princípios ético-jurídicos que estão na base da defesa do ecossistema, do qual depende a vida humana e dos demais seres vivos ${ }^{77}$. O Direito dispõe de enorme força para dar afetividade à sustentabilidade como valor.

Com efeito, a ascensão da sustentabilidade como um valor caracteriza evolução extremamente importante na defesa do meio ambiente humano, porque significa atribuir um significado qualitativo nas decisões políticas, de modo que o Estado possa direcionar o crescimento da economia de modo compatível com o

\footnotetext{
${ }^{76}$ STF. Arguição de descumprimento de preceito fundamental no 101/DF. Brasil: Brasília, 2009.

77 GOMES, Sergio Alves. Hermenêutica constitucional: um contributo à construção do estado democrático de direito, p. 171.
} 
BERGAMASCHI, Joice Duarte Gonçalves; AROSEMENA, Rebeca Isabel Muñoz; GOMES, Sergio Alves. A sustentabilidade como um valor. Revista Eletrônica Direito e Política, Programa de Pós-Graduação Stricto Sensu em Ciência Jurídica da UNIVALI, Itajaí, v.13, n.3, $3^{\circ}$ quadrimestre de 2018. Disponível em: www.univali.br/direitoepolitica - ISSN 1980-7791

desenvolvimento sustentável, que compreende o respeito ao espaço onde vivem os seres humanos como direito inerente à própria vida humana.

\section{CONSIDERAÇÕES FINAIS}

O desenrolar das atividades humanas tem caráter insustentável desde os primórdios da existência do homem na Terra. A poluição ambiental, a escassez de recursos naturais, o advento de tempestades tropicais, terremotos e outros eventos naturais, contudo, levantaram questionamentos acerca da capacidade do planeta de absorver tantas ações de destruição. Em verdade, o meio ambiente passa a dar, cada vez mais, evidentes sinais de que o limite se aproxima.

Com efeito, atribuir à sustentabilidade a característica de valor supremo consubstanciado no texto constitucional revela toda a sua carga axiológica, que atua no sentido de promover o verdadeiro desenvolvimento das sociedades humanas, a fim de que todas as atividades individuais, coletivas, públicas e privadas, tenham por fim máximo a promoção de bem-estar aos indivíduos em sociedade.

Assim, analisar a sustentabilidade como um valor impõe um agir ético às ações humanas, de responsabilidade para com o espaço de onde retira os frutos para sua existência. A nova ética trazida pelo desenvolvimento sustentável visa superar a crença de que a economia é um fim em si mesmo e que o ser humano possa ser mero instrumento para a perseguição de fins lucrativos: o meio ambiente e o ser humano têm completa interação e são o centro do processo de desenvolvimento. O crescimento econômico deve ser qualitativo, de modo a ser traduzido em bemestar humano.

O crescimento econômico é parte do desenvolvimento das sociedades, contudo, não é de modo algum suficiente. A riqueza, por si, apenas, não é fator decisivo ao bem-estar coletivo, que depende muito mais do uso que se dá aos instrumentos de aquisição de poderio econômico. Com efeito, a sustentabilidade como um valor exige uma atuação do poder público de direcionamento dos agentes econômicos para a perspectiva qualitativa dos empreendimentos, de modo que sejam considerados aspectos éticos, sociais, ambientais, econômicos e jurídico-políticos. 
BERGAMASCHI, Joice Duarte Gonçalves; AROSEMENA, Rebeca Isabel Muñoz; GOMES, Sergio Alves. A sustentabilidade como um valor. Revista Eletrônica Direito e Política, Programa de Pós-Graduação Stricto Sensu em Ciência Jurídica da UNIVALI, Itajaí, v.13, n.3, $3^{\circ}$ quadrimestre de 2018. Disponível em: www.univali.br/direitoepolitica - ISSN 1980-7791

E dentro da ideia de que os valores, princípios e normas superiores são conceitos jurídicos que mantêm relações íntimas, importantíssima é a atuação do Poder Judiciário no sentido de fazer valer, no âmbito dos casos concretos de sua competência, os valores constitucionais que direcionam o propósito de todo o ordenamento jurídico. E isso, inclusive na esfera ambiental, onde a sustentabilidade merece especial proteção, pelas razões axiológicas supra invocadas, visando a salvaguarda da vida no Planeta, em todas as suas formas de manifestação. Só assim, a vida humana, inserida que se encontra em tal ecossistema, também poderá se manter de forma sustentável e não de modo periclitante, conforme já vem ocorrendo, segundo múltiplos alertas oriundos inclusive da ciência hodierna.

\section{REFERÊNCIAS BIBLIOGRÁFICAS}

ALEXY, Robert. Teoria dos direitos fundamentais. Tradução de Virgílio Afonso da Silva. 2a Edição, 4a tiragem. São Paulo: Malheiros Editores, 2015.

BALIM, Ana Paula Cabral. MOTA, Luiza Rosso; SILVA, Maria Beatriz Oliveira da. Complexidade ambiental: o repensar da relação Homem-Natureza e seus desafios na sociedade contemporânea. Revista Veredas do Direito. Belo Horizonte, v. 11, n. 21, p. 163-186, 2014.

BIZAWU, Kiwonghi; ROCHA, Marcelo Antonio. Meio ambiente e fundamentos éticomorais e filosóficos: o despertar da conscientização ecológica. In: Direito ambiental e socioambientalismo [Recurso eletrônico on-line]. Coord.: Carlos Frederico Marés Filho, Livia Gaigher Bosio Campello, Norma Sueli Padilha Florianópolis: CONPEDI, 2015.2 Disponivel em: https://www.conpedi.org.br/publicacoes/c178h0tg/gb7cf8t2/B6fIPDgl425464D8. pdf. Acesso em: 05 de maio de 2018.

BONAVIDES, Paulo. Curso de Direito constitucional. 13a Ed. São Paulo, Malheiros, 2003.

BRASIL. Constituição da República Federativa do Brasil de 1988. Brasília: Congresso Nacional, 1988.

DERANI, Cristiane. Direito Ambiental Econômico. 3. ed. São Paulo: Saraiva, 2008.

DIAMOND, Jared. Colapso: como as sociedades escolhem o fracasso ou o sucesso. Rio de Janeiro: Record, 2005.

FREITAS, Juarez. Sustentabilidade: direito ao futuro. $2^{\mathrm{a} e d .}$ Belo Horizonte: Editora Forum, 2012. 
BERGAMASCHI, Joice Duarte Gonçalves; AROSEMENA, Rebeca Isabel Muñoz; GOMES, Sergio Alves. A sustentabilidade como um valor. Revista Eletrônica Direito e Política, Programa de Pós-Graduação Stricto Sensu em Ciência Jurídica da UNIVALI, Itajaí, v.13, n.3, $3^{\circ}$ quadrimestre de 2018. Disponível em: www.univali.br/direitoepolitica - ISSN 1980-7791

GOMES, Sergio Alves. Hermenêutica constitucional: um contributo à construção do estado democrático de direito. Curitiba: Juruá, 2008.

LEFF, Enrique. Saber ambiental: sustentabilidade, racionalidade, complexidade, poder. Tradução de Lucia Mathilde Endlich Orth. 9. ed. Petrópolis, RJ: Vozes, 2012.

MILARÉ, Édis. Direito do ambiente. 9. ed. São Paulo: Revista dos Tribunais, 2014.

OST, François. A natureza à margem da lei: a ecologia à prova do direito. Lisboa: Instituto Piaget, 1997.

PARGA, Milagros Otero. Valores constitucionales: introducción a la filosofia del derecho: axiología Jurídica. Universidade, Servicio de Publicación e Intercambio Científico: Santiago de Compostela, 1999.

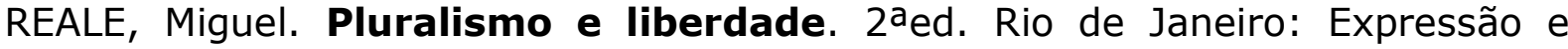
Cultura, 1998.

ROBLES, Gregorio. Os direitos fundamentais e a ética na sociedade atual. São Paulo: Civitas, 1995.

RIBEIRO DOS SANTOS, Antônio Silveira. Homem-natureza: a nova relação ética. In: Tribuna S. Carlos-SP - 12.05.96; - JBA -Gr. Jornal. Ronaldo Cortês-SP19.07.96; Revista Meio Ambiente Industrial. SP- jan. / Fev. 1998 (variação com o título "Ética ambiental: novo paradigma industrial").

TÁRREGA, Maria Cristina. V. B.; PÉREZ, H. L. A. A tutela jurídica da biodiversidade: a influência da convenção sobre a diversidade biológica no sistema internacional de patentes. In: Meio Ambiente e Desenvolvimento Sustentável. Org. TARREGA, Maria Cristina V. B. B. São Paulo: RCS Editora, 2007.

SARMENTO, Daniel. Filosofia e teoria constitucional contemporânea. Rio de Janeiro: Lumen Juris, 2009.

SILVA, José Afonso. Curso de direito constitucional positivo. $20^{\circ}$ ed. São Paulo: Malheiros Editores, 2002.

STF. Arguição de descumprimento de preceito fundamental no 101/DF. Brasil: Brasília, 2009.

VEIGA, José Eli da. Sustentabilidade: a legitimação de um novo valor. São Paulo: Editora Senac São Paulo, 2010.

Recebido em: 12/06/2018

Aprovado em: 05/07/2018 